LA-UR -83-2959

$$
\text { CONF-831015-9 }
$$

\title{
TITLE. A PORTABLE BETA SPECTROMETER/DOSIMETER
}

\section{DESA 001714}

AUTHOR(S): B.H. Erkkila, D.A. Waechter, and R.J. Brake

\author{
SUBMITTED TO: 1983 IEEE Nuclear Science Symposium \\ San Francisco, CA. \\ October $19-21,1983$

\section{DISCLAIMER}

\begin{abstract}
This report was propared as an acoount of work sponsored by an aconcy of the Unitad Stalea Government. Noither the United States Government nor any agency thereof, nor any of their employees, makes any warranty, expreas or implied, or aseumes any lezal liability or reaponaibility for the accuracy, completencen, of usofulneas of any information, apparatus, product, or proceses discloced, or represents that its use would not infringe privately owned rights. Roference herein to any apocific commercial product, proceses, of servioe by trade nume, trademark, manufacturer, of othet wise does not necosarily constitute of imply itu endorsement. recommondation, of favoring by the United Stutea Government or any agency theresf. The viow and opinions of authon expreaned herein do not necessarily atate of roflect those of the United Statea Government or any acency thereof.
\end{abstract}

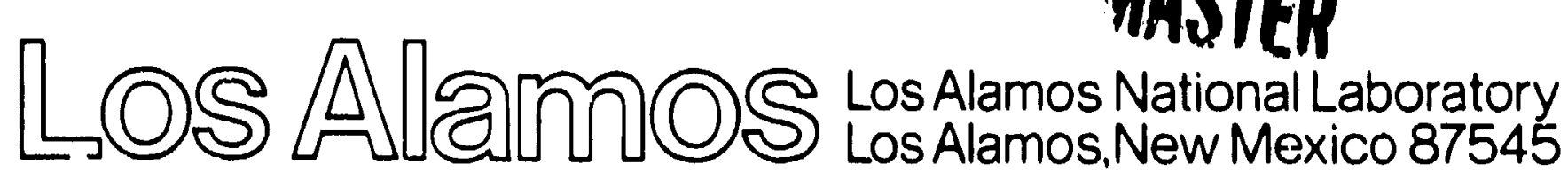




\section{A PORTABLE BETA SPECTROMETER/DOSIMETER}

B. H. Erkktla, D. A. Waechter, and R. J. Brake

Los Alamos National Laboratory

Los Alamos, New Mexico 87545

SUMMARY

As part of an ongoing programi.2 to upgrade health and safety radiation survey instruments, the Los Alamos National Liboratory has developed a portable, battery-operated, computerized beta spectrometer/ dosimeter. The instrument will support many different detectors, but the one chosen here is a combination plastic scintillator and $\mathrm{Nal}$ crystal. The instrument includes pulse conditioning circuits, 128-channel pulse neight analyzer with integral i iquid crystal display, and a microcomputer system which calculates dose and dose rate from betas incident on the detector. Instrument operating life is about 8 hours between charges. The instrument will, at the user's option, display a beta spectrum or the accumulated dose in millirad, as well as give the user beta dose rates in millirad per hour. (At this point, the dosimetry al gori thms are still under development.) Data accumulated in the instrument can be read out through an RS-232 serial port on the instrument. The entire unit weigns 8 pounds, including internal batteries, and is packaged in a small case $25-\mathrm{cm}$ long, $15-\mathrm{cm}$ wide, and 15-cm high.

\section{GENERAL DESCRIPTION}

The beta spectrometer/dosimeter was developed to provide the nealth protection techniclan with a portable instrurent sophisticated enough to account for the beta energy-dependent nature of both the detector response and tre dose distribution in tissue. The ins trument shown in Fig. I t Fackaged in a single case $25-\mathrm{cm}$ long, $15-\mathrm{cm}$ wide, and $15-\mathrm{cm} \mathrm{high}$, weighing $3.8 \mathrm{~kg}$. Controls consist of a power switch and a 16 -key keyhoard which calls all of the spectrometer and dosimeter functions of the instrument. The instru ment is powered by a set of 6 AA NiCd batteries which have an average iffetime between charges of 8 hours. The instrument may also be powered indefinitely off its accessory battery charger.

The beta spectrometer/dosimeter uses a small beta-ray detector bullt hy bicron. Inc. which is capable of measuring the esiergy of beta rays from $100 \mathrm{keV}$ to about $4 \mathrm{MeV}$. The instrument performs spectrum unfolding and conversion of fluence to absorbed dose versus depth in tissue. Other thin $\mathrm{dE} / \mathrm{dx}$ detectors will be evaluated with this system too.

\section{ELECTRONIC DESCRIPTION}

A block diogram of the beta suectrometer/dosimeter is snown in Flg. 2. The electronic circult consists of three basic sections: input signal processing unit, microcomputer, anc dieplay.

The input section is a standard pulse netght an. - lyzer fron: end. Pulses from the detuctor ore shaped onc amplifled by a preamp and then ore fed, with the proper timing. to an $8-b i t$ onalog-an-digital cenverter. The converter outputs a digltal word whose amplitude is proportional to the neight of the input pulse.

The microcomputer is desi gned around an NSCBOO low power CMOS microprocessor manufactured by Nattonal semiconactor. The microprocessor is supported by $16 \mathrm{~K}$ bytes of data mer, ry, all of which are low power cmos in nroer to keep bettery oreill to a minimum. The memory has been made sufficiently large to allow for future expansion of functions in the instrument. The user cormunicates with the computer through a 16key keyboard located on the front panel of the instrument. With the keyboard, ill of the functions and display modes can be readily called up.

The display is a dot matrix LCD array 80 dots wide and 28 dots high. The microcomputer conmunicates with it through two logic cards, one of which is provided by the display manufacturer as part of the display package The display logic contains all the circults necessary to convert the data from the microcomputer to readable spectral or dose information, as required. Also part of the display logic is an on-board memory array which stores current display information. This array, with

its associated logic, refreshes the display periodtcally so that the control processor does not have to be tied up for icng periods, rewriting the same data to the display over and over.

\section{FUNCTIONAL DESCRIPTION}

All of the functions of the instrument ore acces. stble via the keyboard located on the front panel. Thi. keyboard includes keys to generate and move pulse height spectra, generate dose information, and initiate data acpisisition.

Dota acquisition is controlled by two keys, ACQ and HLT. The acquire key, ACQ, causes the Iriput circuits to be enabled and initiates input signal processing by the microprocessor. Signal processing continues until the halt key, HLT, is pressed. The HLT kay inhibits the passage of further input pulses through the system.

There are flue keys which allow the operator to generate various types of displays. Of these five, all but the DOSE key cause different types of spectra to be generated. Pressing the DOSE key will cause the microprocessor to calculate accumulated dose and dose rate from the raw data. This information is then displayed on the LCD in units of mllilirad, millirem, mllilrad/hr. and militrem/hr. A pulse neinht spectrum of incoming date will be generated on the display when the OATA key is pressed. Pressing the $L O G$ key yields. spectrum of the same date displayed in semilog format. When the RAD key is pressed, the instrument will display a plot of the dose in militrads as a function of energy in keV. The REM key performs a simflar function but displays the dose in millitem as a function of energy.

Four modify keys ere providad on the instrument to modify displayed spectra, olding in the and lysis of spictral informatie. The up arrow and down errow keys are vertical scale control keys. When pressed, they scale the spectrum up or down. The left arrow key rolls the 80-channel display left horizontelly, ten channels at atime, so that 111 i28 channels of any spectrum may be viewed. In the same fashion. the right orrow key rolls the display to the right cen channels it itme.

Finally there are two control keys on the keyboard. The first is the CLR key. The CLR key simply clears whetever is being displeyed, be it dose or spectral informetion. fhis key serves as on ald in callbrating the gain of input circults and finds use 


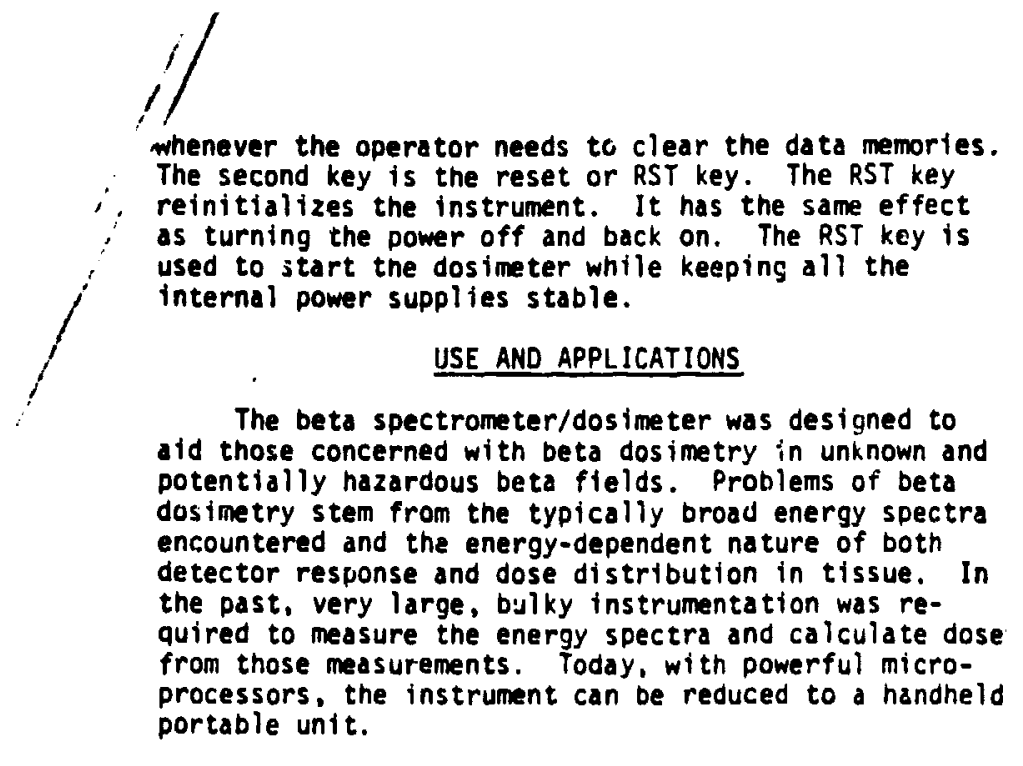

\section{ACKNOWLEDGEMENTS}

The authors wish to thank $k$. Dolberg of the International Tecnnology Division for excellent fllustration services. Also, our thanks to $F$. Trujillo for mechanical design and fabricition support.

\section{REFERENCES}

i. C. J. Umbarger, G. O. Bjarke, B. H. Erkkila, F. Trujillo, D. A. Waechter, and M. A. Wolf, "New Generation of Radiacs: Small Computerized Multipurpose Radiation Monftors," IEEE Trans. NuCl. Sci., NS-30, No. I (1983) p. 528.

2. D. A. Waechter, B. H. Erkkila, and D. B. Vasilik, "A Portable Neutron Spectrometer/Dos imeter.' IEEE Trans. Nucl. Sci., NS-30. No. I (1983) p. 525. 


\section{Figure Captions}

Fig. 1. Portabie Beta Spectrometer/Dosimeter

Fig. 2. Electronics block diagram 


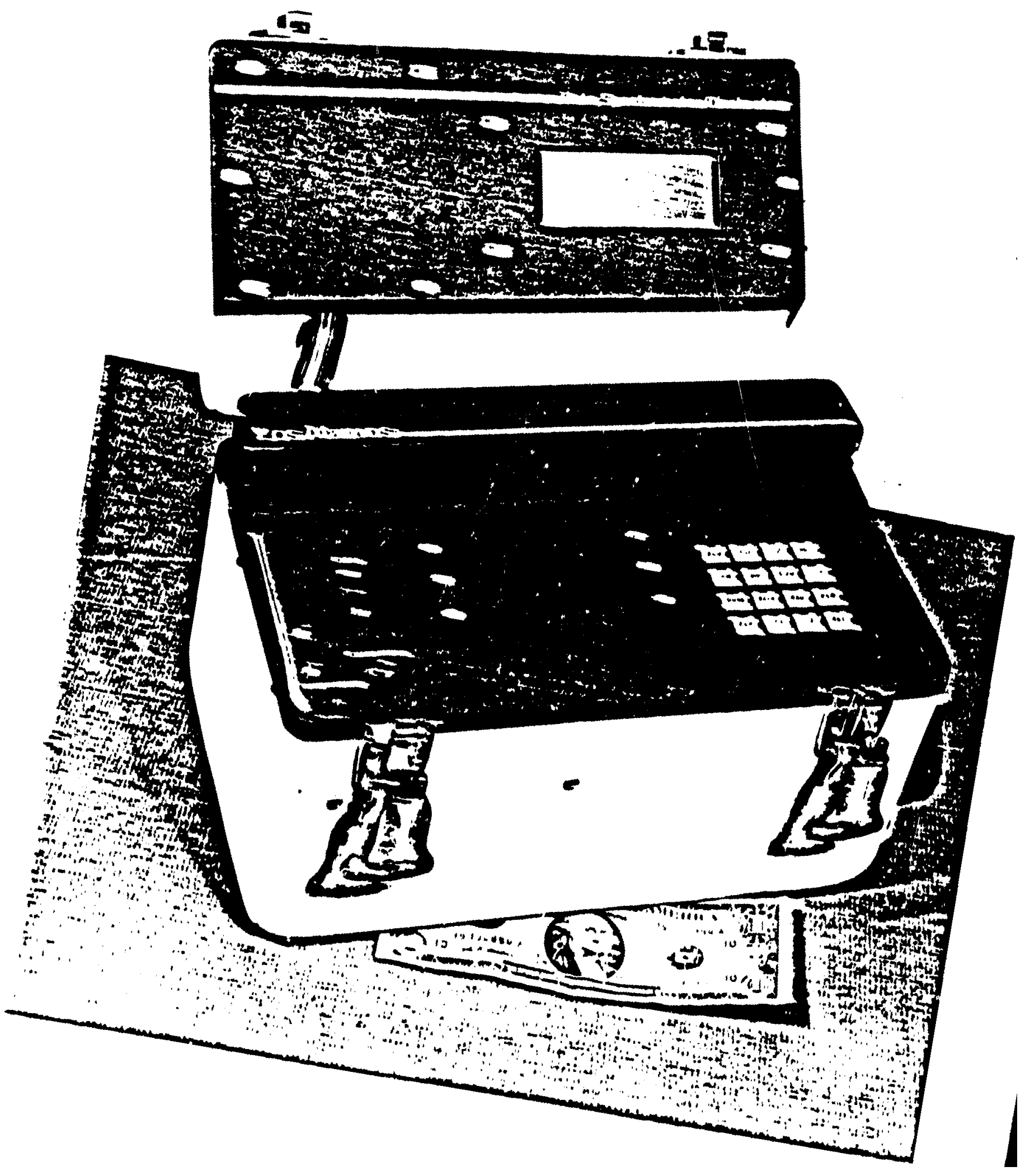




\section{A PORTABLE BETA SPECTROMETER/DOSIMETER BLOCK DIAGRAM}

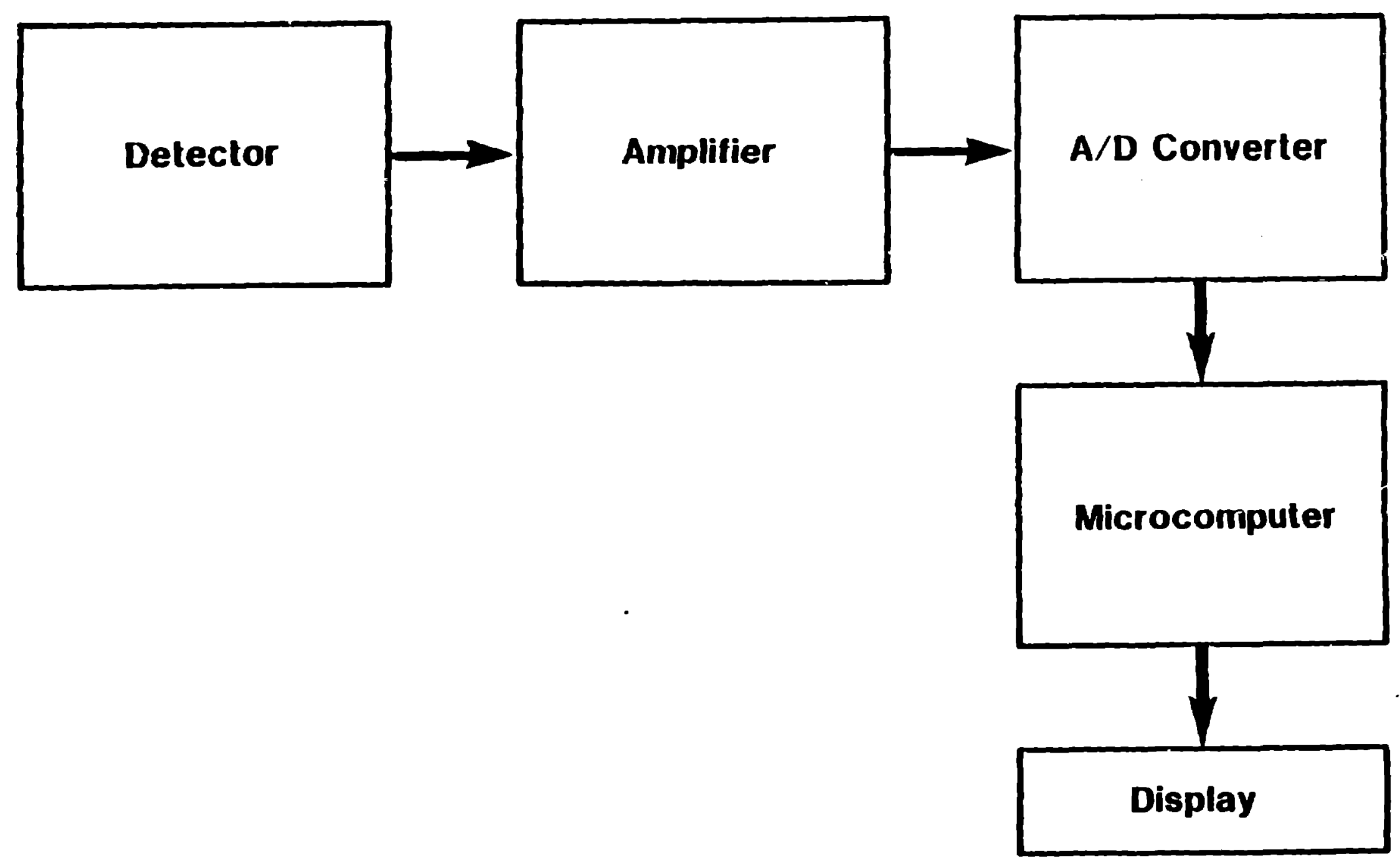

